1 J. Hanson and J. Lowy, J. Mol. Biol., 6 (I963) 46.

2 U. L. Karlsson, W. F. H. M. Mommaerts and F. S. Sjöstrand, Abstr. and Annual Meeting Am. Soc. Cell Biol., i962, p. 88.

3 M. Kasat, S. Asakura and F. Oosawa, Biochim. Biophys. Acta, 57 (1962) 22.

4 F. Oosawa and M. Kasai, $J$. Mol. Biol, 4 (1962) io.

5 'T.-C. Tsao, Biochim. Biophys. Acta, I I (I953) 227.

${ }^{6}$ W. F. H. M. Mommaerts, Ann. Rev. Biochem., 23 (I954) 38 I.

7 E. P. Geidusche and A. Holtzer, Advan. Biol. Med. Phys., 6 (1958) 431.

8 C. M. Kay, Biochim. Biophys. Acta, 43 (r960) 259.

${ }^{9}$ T. OO1, J. Biochem., 50 (I96I) I 28.

10 W. F. H. M. Mommaerts, J. Biol. Chem., 198 (1952) 459.

11 W. F. H. M. Mommaerts, J. Biol. Chem., I 98 (1952) 445.

12 A. M. Katz and W. F. H. M. Mommaerts, Biochim. Biophys. Acta, 65 (1962) 82.

13 M. E. Carsten and W. F. H. M. Mommaerts, Biochemistry, 2 (1963) 28.

14 R. C. Strohman And A. J. Samorodin, J. Biol. Chem., 237 (I962) 363.

15 S. Asakura, Arch. Biochem. Biophys, 92 (I961) I 40.

16 P. D. Boyer, J. Am. Chem. Soc., 76 (I954) 433 I.

Received February I2th, I963

* Advanced Research Fellow of the American Heart Association.

Biochim. Biophys. Acta, 78 (1963) 226-228

Sc 2278

\title{
Preparation of protein-protein conjugates and some novel polyamino acid derivatives employing a bifunctional reagent
}

The bifunctional reagent, $p, p^{\prime}$-difluoro- $m, m^{\prime}$-dinitrodiphenylsulfone ${ }^{1}$, was previously shown to react with bovine serum albumin forming both intra- and intermolecular cross-linkages, as the reaction products contained significant amounts of covalently linked dimers of bovine serum albumin ${ }^{2}$. The cross-linkages apparently involved the lysine and tyrosine residues of the protein ${ }^{2-4}$. The formation of $p, p^{\prime}$-difluoro- $m, m^{\prime}$ dinitrodiphenylsulfone-mediated cross-linkages across protein molecules was also confirmed by the demonstration that the reaction of a mixture of antibody and ferritin in the presence of the reagent resulted in the formation of antibody-ferritin conjugates $^{5}$ suitable for immuno-electron microscopy $y^{6,7}$. Further studies, demonstrating the wide usefulness of $p, p^{\prime}$-difluoro- $m, m^{\prime}$-dinitrodiphenylsulfone as a general reagent for the preparation of (a) protein-protein conjugates, and (b) long-chain, non-dialyzable polyamino acid derivatives, are reported here. The latter compounds, similar to proteins in containing amino acid chains, but dissimilar to them in the manner in which the amino acids are joined, may serve as model compounds for understanding the manifold physicochemical and biological activities of proteins as macromolecules, antigens, etc. As sulfones they may be of interest to the pharmacologist.

Employing $p, p^{\prime}$-difluoro- $m, m^{\prime}$-dinitrodiphenylsulfone, conjugates of the following pairs of proteins have been prepared; ferritin-bovine serum albumin ; ferritin-human albumin; ferritin-bovine globulin; bovine serum albumin egg albumin; and bovine serum albumin-globulin (from rabbit, horse, man, etc.). In each case, the formation of a third component with an electrophoretic mobility intermediate to that of the

Abbreviation: NPS, nitrodiphenylsulfone. 
reacting proteins was taken as evidence for the formation of the conjugate. As a representative procedure, the preparation and purification of the conjugate of bovine serum albumin with horse globulin is described. $500 \mathrm{mg}$ each of bovine serum albumin and the globulin were dissolved in $\mathrm{ro} \mathrm{ml}$ of cold $\mathrm{r} \% \mathrm{Na}_{2} \mathrm{CO}_{3}$ and the $\mathrm{pH}$ was adjusted to I0.8. $3 \mathrm{ml}$ of acetone containing $25 \mathrm{mg}$ of $p, p^{\prime}$-difluoro- $m, m^{\prime}$-dinitrodiphenylsulfone was slowly added with stirring and the reaction allowed to proceed in the cold $\left(2-4^{\circ}\right)$ with stirring until clear $(2 \mathrm{~h})$. The reaction mixture was then exhaustively dialyzed against normal saline. After dialysis, exactly half its volume of cold, neutral, satd. $\left(\mathrm{NH}_{4}\right)_{2} \mathrm{SO}_{4}$ was added to the protein solution. The precipitate obtained was dissolved in $20 \mathrm{ml}$ of chilled distilled water and reprecipitated with $\mathrm{Io} \mathrm{ml}$ of satd. $\left(\mathrm{NH}_{4}\right)_{2} \mathrm{SO}_{4}$. The precipitation, followed by dissolution in water, was repeated twice more whereupon the supernatant was colorless and the precipitate contained electrophoretically pure conjugate (cellulose acetate paper electrophoresis; barbital buffer, $\mathrm{pH}$ 8.6). It was dissolved in the desired volume of normal saline and dialyzed against saline.

Significant amounts of non-dialyzable derivatives (poly NPS-amino acids) were formed on reacting $p, p^{\prime}$-difluoro- $m, m^{\prime}$-dinitrodiphenylsulfone with lysine, tyrosine, histidine, cysteine, arginine, citrulline, and a variety of their mixtures. With glycine, aspartic acid, serine, valine, threonine and hydroxyproline only dialyzable products were obtained. The preparation of poly NPS-lysine, described below, is broadly applicable to the other amino acids also. In a reaction carried out at room temperature $400 \mathrm{mg}$ of lysine dihydrochloride were dissolved in $40 \mathrm{ml}$ of $2 \% \mathrm{Na}_{2} \mathrm{CO}_{3}$ and the $\mathrm{pH}$ adjusted to Io-I0.5. This solution was added dropwise, with stirring, to ro $\mathrm{ml}$ of acetone containing Ioo $\mathrm{mg}$ of $p, p^{\prime}$-difluoro- $m, m^{\prime}$-dinitrodiphenylsulfone. The reaction mixture which immediately turned yellow and turbid gradually clarified when all the amino acid was added. After standing for $4-6 \mathrm{~h}$, the contents were exhaustively dialyzed against distilled water until all yellow diffusible material escaped. The final product was lyophilized (yield, 50-75 mg).

Poly NPS-lysine could also be obtained by the following procedure. The reaction mixture was aerated to remove most of the acetone and a calculated volume of satd. $\mathrm{NaCl}$ ( $45 \mathrm{ml}$ per Ioo $\mathrm{ml}$ of reaction mixture) was added with mixing. After standing for $30 \mathrm{~min}$, the precipitate was centrifuged off, dialyzed against water and lyophilized.

The various poly NPS-amino acids were soluble in o. I $\mathrm{N} \mathrm{NaOH}$, sparingly so in water, and insoluble in o.I N HCl. After dissolution in alkali their solutions could be neutralized and stored for prolonged periods without precipitation. The sedimentation patterns of bovine serum albumin and poly NPS-lysine are compared in
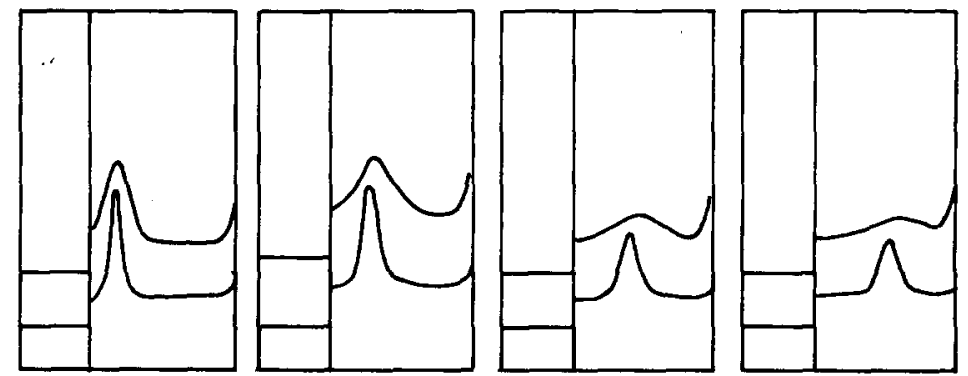

Fig. I. Sedimentation behavior of poly NPS-lysine (upper pattern) and bovine serum albumin (lower pattern) compared in a Spinco Model E ultracentrifuge. Speed, $59780 \mathrm{rev} . / \mathrm{min}$; temperature, $20^{\circ}$; solvent, o.r M NaCl. From photographs taken at 16 -min intervals. 
Fig. I. The other poly NPS-amino acids exhibited similar protein-like sedimentation characteristics. On cellulose acetate paper electrophoresis (barbital buffer, pH 8.6) the various derivatives exhibited mobilities comparable to bovine serum albumin. Interestingly, they exhibited "precipitin reactions" in OUCHTERLONY geldiffusion experiments ${ }^{8}$ with $\beta$ - and $\gamma$-globulins, fibrinogen and trypsin but not with $\alpha$-globulin, various serum albumins, ferritin, egg albumin, pepsin or chymotrypsin. These "precipitin reactions" appear to be related to the isoelectric points of the proteins in question.

These studies were supported by Grant No. E440I, U.S. Public Health Service.

The author wishes to thank M. Mrazovich and M. ChEOng for technical assistance.

Department of Pathology, The University of Michigan,

J. SRI RAM

$$
\text { Ann Arbor, Mich. (U.S.A.) }
$$

1 H. ZahN AND H. ZuBER, Ber., 86 (1953) I 72.

2 S. S. Tawde, J. Sri Ram and M. R. Iyengar, Avch. Biochem. Biophys., Ioo (Ig63) 270.

${ }^{3}$ F. Wold, J. Biol. Chem., 236 (I96I) Io6.

4 F. Wold, Biochim. Biophys. Acta, 54 (1961) 604.

5 S. S. Tawde and J. SRI Ram, Arch. Biochem. Biophys., 97 (1962) 430.

6 J. Sri Ram, S. S. Tawde, G. B. Pierce, Jr. And A. R. Mrdgley, Jr , J. Cell Biol., r7 (1963) 673.

7 G. B. Pierce, Jr, A. R. Midgley, Jr. and J. Sri Ram, J. Exptl. Med., i i 7 (ig63) 339.

\& O. Ouchterlony, Progy. Allevgy, 5 (1958) I.

Received February 25th, I963 